\title{
New Record of Mozambique Scorpionfish, Parascorpaena mossambica (Peters, 1855), (Actinopterygii: Order, Scorpaeniformes; Family, Scorpaenidae) from Indian Waters
}

\author{
Muddula Krishna Naranji*, Govinda Rao Velamala and Kandula Sujatha \\ Department of Marne Living resources, College of Science and Technology, Andhra University, \\ Visakhapatnam-530003, Andhra Pradesh, India \\ Email: krishna.muddu217@gmail.com
}

\begin{abstract}
Parascorpaena mossambica is one of the rare species of Scorpaenidae in the Visakhapatnam coastal waters, India. Ten specimens are characterized by Dorsal fin IX 9; Anal fin III 5-6; Pectoral fin rays 15; Lateral line scales 43-44; Lateral line Pored scales 23-24; Lateral transverse scale scales 6-7/1/12-14; lachrymal bone with two lower strong antrose spines, anterior pointed and directed forward, tip reaching dorsal margin of upper lip, covered with skin; posterior one directed forward and slightly downward; suborbital with three spines. Only few records have been made in the whole Indian waters. Due to its rarity, $P$. mossambica is poorly studied and little known about their biology, ecology and distribution. In the present study provides additional data on this rare species. In particular, we describe its habitat, ecology, presence and distribution with several new records in Indian waters.
\end{abstract}

Keywords: Scorpaenidae, fish, Parascorpaena mossambica, Visakhapatnam

\section{Introduction}

The family Scorpaenidae, with about 375 species, in one of the largest families of fishes, distributed worldwide in both tropical and temperate waters (Fischer and Bianchi, 1984), (Froese and Pauly, 2016); Neslon et al. (2017). In India, there are many new and rare scorpaenids reported Russell (1803), Day (1875) (Krishna and Rao, 2015), Krishna (2016), (Krishna and Rao, 2016), Krishna et al. (2017). Identification of Indo-Pacific scorpion fishes in their natural environment is possible in most cases. Important diagnostic features are the presence and the morphology of the head spines, morphology of cirri and other interorbital tentacles, the morphology of the head and particular and constant pattern (Randall and Eschmeyer, 2001).

With the recent discovery of a new record from Japan Motomura et al. (2011), the genus Parascorpaena includes six species of Indo-Pacific origin. Some species of this genus are very similar in morphology and coloration. Considering this, it is not always possible to identify the species in the natural environment. Most of the species are present in the Western part of the Atlantic Ocean, while the remaining species are present in its Indo-Pacific part.

The Mozambique scorpion fish, Parascorpaena mossambica, was thought to be well- known from east Africa to the Marquesas Islands, but was in recent times classified by Motomura et al. (2011) to the Indian seas, reaching from east Africa to western Indonesia. Outside this range, the species was recorded (as Scorpaena longicornis) from Sudan, Red Sea in check list by Bamber (1915) without any further data. Genus Parascorpaena is a little known uncommon species distributed in IndoPacific oceans: Red sea, Mozambique and Papua New Guinea, East Asia, Yakushima Island Fischer and Bianchi (1984), Kailola (1987), Motomura et al. (2009), (Allen and Erdmann, 2012). Species belongs to the family Scorpaenidae under Scorpaeninae subfamily and Scorpaenini tribe. The Mozambique scorpion fish, Parascorpaena mossambica, is relatively rare in rocky and coral reefs in shallow tropical waters. Genus Parascorpaena fish characterized by having an anteroventrally directed posterior lacrimal spine and cycloid scales Fricke et al. (2015), Parascorpaena Bleeker, 1876 comprises a total of 8 valid nominal species (Eschmeyer and Fricke, 2015).

Curiously, in Indian waters, the presence of this species appears to be confined in rocky intertidal shore areas of the Indian waters. In India, other coastal areas, this species has never been reported, not even in West coast of India. In our opinion, In fact, in Visakhapatnam coastal waters the rocky shore species was always observed in 
Intertidal areas and harbour areas, rocky and sandy shore beaches in the immediate vicinity of areas that are considered "hotspots" for the introductions of new and rare species.

P. mossambica (Peters 1855) is the only species of the genus recorded in the Visakhapatnam coastal waters, India and its distribution extends to the East and west coast of India. The species was described as Scorpaena mossambica (Peters 1855) from Ibo, Mozambique, Western Indian Ocean and recent years it was first recorded from Israel, Gulf of Aquab, Red Sea (Fricke et al., 2015). The species was recently classified by Motomura et al. (2011) to the Indian Ocean, occurring from South and East Africa to Western Indonesia.

Concerning Indian records, the species is only reported for East coast of India and its presence is confined to specific environments: Due to its rarity, the biology, reproduction and feeding habits of this species poorly unknown. In particular, information about its ecology, biology, age growth studies are lacking or scarce in literature. The morphological and description of this species refers to few specimens only. Based on several years observation and study both natural environment we are report new data for this rare species. In particular, we analyse and discuss about their length weight relationship studies, habitat preference, abundance and presence in Indian waters. Further specimens from the region are required to assess the occurrence and biological aspects of $P$. mossambica.

\section{Materials and Methods}

Specimens, 10 in total of different sizes of $P$. mossambica were collected from Visakhapatnam coastal waters, India $\left(17^{\circ} 44^{\prime} \mathrm{N}, 83^{\circ} 23^{\prime} \mathrm{E}\right)$ during 2011-2015. The colour of the specimens in the samples was noted in fresh condition. Morphometric and meristic data of the fresh specimens were taken. Data on other characters, including preorbital bone, pyloric caeca and vertebrae were also taken. Specimens of the $P$. mossambica, were identified based on Fischer and Bianchi (1984), Froese and Pauly (2016), and Randall and Eschmeyer (2001). Methodology for morphometric measurements follows Randall and Eschmeyer (2001) and Hubbs and Lagler (1958). Microsoft Excel Software was used for statistical analysis. Terminology of head spines follows Eschmeyer (1969) and Hiroyuki et al. (2009). The specimens were preserved in 5\% formaldehyde and deposited in the department of marine living resources, Andhra University, Visakhapatnam, India.

\section{Results and Discussion}

Parascorpaena mossambica (Peters, 1855) (Figure 1) Description based on 10 specimens measuring 112-140 mm TL (1J, 69 \& 3 $\left.{ }^{1}\right)$ Meristic characters: D IX 9; A III 5-6; V I 5; C 13; P 15; LI4344; Lateral line Pored scales 23-24; Ltr6-7/1/12-14; GR 4-5+1+9=14-16; Pyloric caeca 5; Vertebrae: 24 .

Body oblong, moderately compressed, both profiles convex, ventral less so; dorsal profile of head slightly sloped from nape to snout; A distinct occipital depression, naked. Snout with concavity before eyes; Head large, snout fairly blunt; mouth large, slightly oblique; jaws equal; maxilla long and broad distally, reaches to posterior margin of eye. Interorbital narrow, deeply concave, with low coronal ridges; eyes large and slightly upward, with elevated supraorbital ridges; nostrils close to each other; anterior one round, slightly tubular, with fimbriate flap on posterior edge; posterior one entire, oval, situated on anterior preocular rim. Teeth villiform, in bands on jaws, arrowhead shape teeth on vomers, palatine teeth present; patches of teeth on roof and floor of pharynx. Tongue small, pointed, apex free. Gill opening wide, pseudobranchiae present; no slit below fourth gill arch; gill membrane free from isthmus; gill rakers short, reduced to spiny at either end. Preoperculum round, opercular flap pointed, it reaches near the base of the pectoral origin.

\section{Head spines}

Spines on head well developed; lachrymal with two lower strong antrose spines, anterior pointed and directed forward, tip reaching dorsal margin of upper lip, covered with skin; posterior one directed forward and slightly downward; suborbital with three spines, its hind end usually concealed, close together, pre opercle margin with five spines, upper largest, with small spine on base, the lower two obtuse; opercular spines subequal; supplemental preopercular spine half the length of the first preopercular spine; cleithral spine strong, pointed, directed upward and backward; postorbital spines absent, supracleithral spine present; upper two posttemporal, lower posttemporal, nuchal, nasal, preocular, supraocular, postocular, tympanic, pterotic, humeral, parietal, one or two sphenotic spines present; postfrontal spines absent. Filaments on head, usually one on maxilla, skinny flaps and ridges on upper part of iris often present; none on chin, a few along lateral line, and front of body; two or three on preopercular edge.

Dorsal fins continuous, with notch after last spine of first dorsal; origin above middle of opercle; first spine short, spines increase in length to fourth, which is longest; succeeding spines gradually 
Table1. Percentage of morphometric measurements of Parascorpaena mossambica

\begin{tabular}{|c|c|c|}
\hline \multirow{3}{*}{ Standard length in millimeter, TL } & \multicolumn{2}{|c|}{ P. mossambica $\mathrm{n}=10$} \\
\hline & & \\
\hline & Min-Max & $\bar{X}_{ \pm \mathrm{S} . \mathrm{D}}$ \\
\hline \multicolumn{3}{|l|}{ As percentage of standard length } \\
\hline Total length & $127.27-132.29$ & $129.30 \pm 1.82$ \\
\hline Body depth & $35.71-40.90$ & $38.27 \pm 1.82$ \\
\hline Head length & $42.85-48.51$ & $45.43 \pm 2.12$ \\
\hline Pre dorsal distance & 35.29-39.77 & $37.40 \pm 1.54$ \\
\hline Pre pectoral distance & $38.00-42.59$ & $39.90 \pm 1.80$ \\
\hline Pre pelvic distance & $37.25-41.83$ & $39.40 \pm 1.74$ \\
\hline Pre anal distance & $71.42-76.00$ & $74.06 \pm 1.54$ \\
\hline Dorsal base & $64.81-72.54$ & $69.62 \pm 2.46$ \\
\hline Pectoral base & $16.66-18.81$ & $17.62 \pm 0.79$ \\
\hline Anal base & 17.04-18.75 & $17.92 \pm 0.62$ \\
\hline Dorsal spine height & $15.90-18.00$ & $17.29 \pm 0.77$ \\
\hline Soft dorsal height & $17.34-21.56$ & $20.00 \pm 1.60$ \\
\hline Pectoral length & 29.54-32.40 & $31.40 \pm 0.96$ \\
\hline Pelvic spine height & $13.86-17.64$ & $16.18 \pm 1.30$ \\
\hline Soft Pelvic fin length & 22.72-27.72 & $25.00 \pm 1.90$ \\
\hline Anal spine height & $22.00-25.49$ & $23.38 \pm 1.29$ \\
\hline Soft anal height & 23.52-27.72 & $25.10 \pm 1.47$ \\
\hline \multicolumn{3}{|l|}{ As percentage of head length } \\
\hline Head depth & $71.42-72.27$ & $74.82 \pm 2.00$ \\
\hline Head width & 64.28-71.42 & $69.39 \pm 2.68$ \\
\hline Eye diameter & $17.70-24.44$ & $22.35 \pm 2.32$ \\
\hline Pre orbital distance & $19.60-26.66$ & $23.11 \pm 2.33$ \\
\hline Post orbital distance & 48.93-54.54 & $51.66 \pm 1.77$ \\
\hline Inter orbital distance & $20.00-25.00$ & 22.77-1.79 \\
\hline Upper jaw length & $44.89-51.06$ & $47.51 \pm 2.18$ \\
\hline Lower jaw length & $38.09-45.45$ & $41.93 \pm 2.61$ \\
\hline Maxilla width & $13.63-17.64$ & $15.47 \pm 1.47$ \\
\hline Snout length & 25.53-29.54 & $27.09 \pm 1.51$ \\
\hline Caudal peduncle depth & $11.80-13.80$ & $12.70 \pm 0.64$ \\
\hline
\end{tabular}

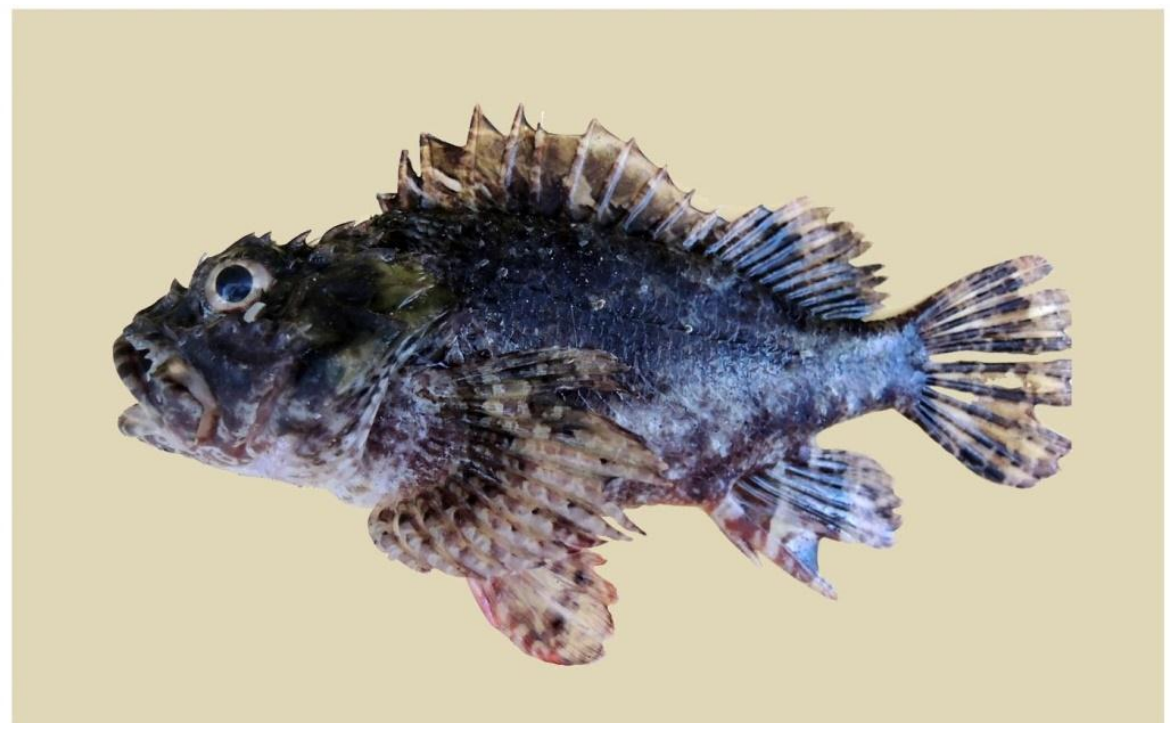

Figure 1. Parascorpaena mossambica (Peters, 1855), $140 \mathrm{~mm}$, TL from India 
decrease in length; single spine of second dorsal longer than last spine of first dorsal; interspinous membrane deeply notched, rays divided, slightly longer than longest spine; pectorals with two to six divided rays, reaches to beyond vent. Pelvics shorter than pectorals, origin behind that of pectorals, reaching to between vent and anal origin. Anal spines strong, second spine longest, stout, rays divided; posterior part of dorsal, anal, pelvic rays rounded. Caudal with rounded.

Scales apparently all cycloid, those on shoulder often crenulated, smaller on belly and chest, which is fully scaled, predorsal scaling ends behind occipital depression. Some scales concealed by skin, below pterotic and and posttemporal spines, the hind most with apical ctenae, the others cycloid. On cheek below suborbital stay usually two, rarely one or three, moderate smooth cycloid scales, completely hidden by skin, interorbital and head otherwise naked, occationally a few small scales on dorsal and anal, but those mostly naked.

\section{Colour}

Variable but characteristic. Body with brownish blotches, alternating dark black bands and light yellowish streaks observed. Head red and yellow, with red marbling and bars on chin and lip, ocular tentacles reddish yellow, spinous dorsal yellowish, spotted and streaked obliquely with red brown and black, soft dorsal yellow with two sub vertical red brown bars. Caudal yellow with red brown base and margin, a broad brown bar across the middle. Anal fin with three red brown bars. Pectorals yellow with faint Red Cross bars, reddish below. Pelvics reddish, vertical fins pink or red, variable, with reddish mottling and bars. Pelvics cleared, red area above axil. Iris dusky red, often brown bars, white skin flaps or tentacles on along lateral line and on sides and head. Opercle area black.

From world waters previously recorded as Scorpaena longicornis Sudan, Red Sea by Froese and Pauly (2016) deprived of any additional documents Goren and Dor (1994) was recorded from Sudan recorded specimen cited. As no specimen from the Red Sea was available in collections and no information about the record had been provided (Golani and Bogorodsky, 2010) came to the conclusion that the record of $P$. mossambica could not be confirmed. Morphological comparisons of the Indo-west Pacific scorpion fish, re-described the species $P$. mosambica on the basis of one specimen (Froese and Pauly, 2016). This species was first described (as Scorpaena mossambica) by Peters (1855) from Ibo, Mozambique, western Indian Ocean. Referring to an unpublished revision of the genus by Eschmeyer (1986) placed th1e species in the genus Parascorpaena Bleeker, 1876, and provided information on its distribution range from South and East Africa to the central Pacific. Parascorpaena is widely distributed in the Indo Pacific, including East Asia Motomura et al. (2009). Day (1875) reported this genus from Indian waters as Scorpaena (non Bleeker). After Day (1875) this is the new record from Indian waters. Local Telugu name "Mora goddu". The present specimens were collected on a rocky shore with algae, at the Visakhapatnam coastal waters, at a depth of 12 metres. The solitary and cryptic occurrence of this species makes it difficult to find it, its hide under the rocks. Parascorpaena species are small, cryptic in colour their behaviour, and may be difficult to see even when out of water, as they may hide under rock or in vegetation and often overlooked colour.

\section{Conclusion}

These results provide new information about the morphology and ecology of this species with notes about its distribution and presence, providing new records for Indian waters. Its looks like as a rocks, so that it may be distributed in the Indian Ocean than the scarce records of this species suggest. In Indian waters, other suitable habitats for this species may be found in the East and West coast of India, as well as on sand or rocky shore throughout the area.

\section{Acknowledgements}

The authors are thankful to University Grants Commission, New Delhi, India for providing fellowship during the study period 2010-2015. Head of the Marine Living Resources department, Andhra University for providing facilities during the entire study period.

\section{References}

Allen, G.R. \& Erdmann, M.V. 2012. Reef fishes of the East Indies. Perth, Australia: University of Hawaii Press, Volumes I-III. Tropical Reef Res. 1126$1129 \mathrm{pp}$.

Bamber, R.C. 1915. Reports on the marine biology of the Sudanese Red Sea, from collections made by Cyril Cross land, M.A., B.Sc., F.Z.S. XXII. The Fishes. J. Lin. Soc. London, Zool. 31(210):477485.

Day, F. 1875. The Fishes of India, London. XX+778., 108 p-ls. (Reprinted WM. Dawson \& Sons, 1958). 
Dor, M. 1984. Checklist of the fishes of the Red Sea. Clofres, Jerusalem, The Israel Acta Scientia and Humngarica.437pp.

Eschmeyer, W.N. \& Fricke, R. (eds.). 2015. Catalog of fishes. California Academy of Sciences, San Franscisco

Eschmeyer, W.N. 1969. A systematic review of the scoropionfish of the Atlantic Ocean (Pisces: Scorpaenidae). Occ. Papers of the Cal. Aca. Sci. 79-130pp.

Eschmeyer, W.N. 1986. Family No. 149: Scorpaenidae. Pp. 463-478. In: Smith M.M. Heemstra P.C. (eds.) Smiths' Sea Fishes. Macmillan South Africa, Johannesburg, RSAS.

Fischer, W. \& Bianchi, G. 1984. FAO species identification for fishery purpose: Western India Ocean. Food and Agriculture organization of the United Nations, Rome, Vol 4. 241 pages

Fricke, R., Golani, D. \& Appelbaum G.B. 2015. New record of the Mozambique scorpionfish, Parascorpaena mossambica (Peters, 1855) (Actinopterygii; Scorpaeniformes: Scorpaenidae), from Israel, Gulf of Aqaba, Red Sea. Actalchthyologicaet Piscatoria.45(4):423-425. doi: 10.3750/AIP2015.45.4.12.

Froese, R. \& Pauly, D. 2016. Fish Base. World Wide Web Electronic publication. www.fishibase.org/ search. php (Accessed 16 August 2016).

Golani, D. \& Bogorodsky, S.V., 2010. The Fishes of The Red Sea Reappraisal And Updated Checklist. Zootaxa, 2463:1-135.

Goren, M. \& Dor, M. 1994. An updated checklist of the fishes of the Red Sea. CLOFRES II. The Israel Academy of Sciences and Humanities, Jerusalem.

Hubbs, C.L. \& Lagler, K.F. 1958. Fishes of the great Lake region. Cranbrook Inst. Science Fish. Bull. 26: 1-213.

Kailola, P.J. 1987. The fishes of Papua New Guinea: a revised and annotated checklist. Vol.II

Krishna, M.N. \& Rao, G.V. 2015. New record of low fin scorpionfish Scorpaenodes parvipinnis Garret (1836) family Scorpaenidae from Indian waters. Adv. Pharmacol. Toxicol. 16(3):69-74.

Krishna, M.N. 2016. First record of raggy scorpion fish Scorpaenopsis venosa (Cuvier, 1829)
(Family: Scorpaenidae) from Visakhapatnam, Central Eastern Coast of India. Int. J. Zoological Stud. 1(5):40-42.

Krishna, M.N., Rao, G.V. \& Sujatha, K. 2017. New record of the fraser Scorpionfish, Scorpaenopsis macrochir (Family: Scorpaenidae) from Indian waters. Bangladesh J. Fisheries. 5(1):1-4. doi: 10.17017/jfish.v5i1.2017.210.

Krishna, M.N., Rao, G.V. \& Venu, D. 2016. Taxonomy diversity, species composition, distribution, conservation and abundance of rocky shore intertidal fishes in the Visakhapatnam, east coast of India. J. Exp. Zool. India. 19(1):277283.

Krishna, MN. \& Rao, G.V. 2016. First record of Rama Rao's scorpionfish, Scorpaenopsis rama rao Randall and Eschmeyer, 2001 (genus: Scorpaenopsis, family: Scorapenidae) from Visakhapatnam, East coast of India. Fish Taxa. 1(2):84-88.

Motomura, H., Béarez, P. \& Causse, R. 2011. Review of Indo-Pacific specimens of the subfamily Scorpaeninae (Scorpaenidae), deposited in the Muséum national d'Histoirenaturelle, Paris, with description of a new species of Neomerinthe. Cybium 35(1):55-73.

Motomura, H., Sakura, Senou, Y. \& Ho H.C.H. 2009. Morphological comparisons of the Indo-West Pacific scorpionfish Parascorpaena aurita, with a closely related species, $P$. picta, with first record of $P$. aurita from East Asia (Scorpaeniformes: Scorpaenidae). Zootaxa. 2195: 34-42.

Neslon, J.S., Grande T.C. \& Wilson, M.V.H. 2017. Fishes of the World. $5^{\text {th }}$ Edn., John Wiley \& Sons, Inc., Published by Hoboken, New Jersey, U.S.A. 752pp. doi: 10.1111/jfb.13229.

Peters, W. 1855. Ubersicht der in Mossambique beobachteten seefische. Bericht uber diezur Bekanntmachunggeeigneten Vehandlungender Koniglichen Preussischen Akademie der Wissenschaftenzu Berlin. 428-466.

Randall, J.E. \& Eschmeyer, W.N. 2001. Revision of the Indo-Pacific scorpionfish genus Scorpaenopsis, with descriptions of eight new species. Indo- Pacific Fishes. 34:1-79.

Russell, P. 1803. Descriptions and Figures of Two Hundred Fishes; Collected at Vizagapatam on 
the Coast of Coromandel, by Patrick Russell. The Hon. the Court of Directors of the East India Company, and Published by Their Order, Under the Superintendence of the Author. Vol II. G. \& W. Nicol. 